\title{
The Signing and Amendments of China's BITs with Countries along B\&R--Analysis Based on Game Theory
}

\author{
Hongle Zhang* \\ PHD of law, Associate Professor of Ningbo Dahongying Univestiy, 899 Xueyuan Rd, Ningbo, China(315175) \\ ${ }^{*}$ Corresponding author
}

\begin{abstract}
According to the game theory, a bilateral investment agreement (BIT) is a multi-player dynamic game, which involves not only contracting countries, but also potential investors. The preamble and purpose of the BIT are to define the scope of the game, while the investment definition is to further refine the scope of the game. During the process of signing the BIT, there are many times of the game process, and the bilateral effect to contracting parties is not the same. For capital-exporting countries, BIT plays a major role in protecting overseas investment; for investment host countries, BIT plays a role in promoting foreign investment. China's OFDI in countries along the Belt \& Road (B\&R) is rising in recent years. Among these countries, some countries are developing countries, while some are developed economies such as the European Union. At the present period China should actively sign and amend BITs with developing countries along B\&R, and maintain the BITs with the developed countries status quo, waiting for substantial progress in the negotiations of BIT with EU.
\end{abstract} theory

Keywords-bilateral investment treaty(BIT); B\&R; game JEL: K33; C79; F21

\section{INTRODUCTION}

In recent years, China has transformed itself from a developing country that absorbs the largest foreign investment into a country with the most OFDI. In the meantime, China has signed more than 130 BITs overseas, making China one of the countries with the largest BITs after Germany. Since China put forward "B\&R (B\&R) Initiative" in 2003, China's investment in countries along B\&R started to increase rapidly. Among 64 countries along B\&R, China has already signed 56 BITs among them。However, the time frames for signing these agreements are very large, and the quality and content of BITs are also quite different. This article attempts to analyze the legal nature of BIT by using game theory as a basis for making recommendations on China's practice of BITs in countries along B\&R.

Game theory originated in the early 20th century. Nash proved the existence of the non-cooperative game equilibrium in the 1950s and proposed the famous Nash equilibrium, which revealed the connection between game equilibrium and economic equilibrium and created a new era of game theory. The law not only focuses on the individual's reaction to legal rules, but on the mutual reactions of common people under the rule of law. The basic characteristic of the countermeasure behavior analyzed by game theory is that the formation of behavior is not only a function of its own constraints, it is also a function of the opposite party in the game. Therefore, in a legal relationship, the choices of the legal subjects involved are not only influenced by their own factors, but also influenced by the behavior of other parties ${ }^{[1]}$.

In the legal relationship of BITs, because there are many game players, it is a multi-player game. However, due to the different positions of these subjects, different game strategies are inevitable. These will inevitably affect the effectiveness of bilateral investment agreements on both parties.

\section{PARTICIPANTS IN THE GAME--STAKEHOLDERS IN BITS}

The main contracting parties to the BITs are states, and the treaties are usually signed by the central governments on behalf of their country. The states are both rule makers and rule observers. According to Pacta sunt servanda, when a country has signed a treaty, it must abide by the treaty and do it in accordance with the provisions of the treaty. Therefore, once the treaty is signed, the state must play the game on the basis of the treaty and bear unfavorable consequences such as international responsibility if it violates the treaty. At the same time, the process of contracting is also a dynamic game between two parties. Bargaining in negotiations is a concentrated expression of this game. After the treaty is signed, it does not mean that the game between countries on how to sign the law ended. Amendments, renewing and renegotiations after the signing of treaty, and so on are all game behaviors of the two parties. Even the act of threatening to withdraw from the treaty by one of the parties is also a manifestation of the game.

In addition to these two important subjects, there are a large number of but not insignificant subjects in the legal relationship of BITs, namely, investors in both sides.

If these investors have already intended to invest in each other's territory, they have become the subject of the legal relationship of the bilateral investment agreements because these investors must meet the requirements of BIT and the domestic laws of the other party at the same time. For these investors, there has been a round of games, because the process of their investment decision-making is a game process de facto. In the course of this game, the contents of each other's domestic laws and BITs are the functions they need to refer to, 
and at the same time they make decisions based on their own circumstances and various market factors.

For those investors who have not invested in each other's territory, they are just potential investors and or potential game players. During such kind of 'game', they can make decisions on investing in each other's territory and become the main body of BIT's legal relationship. They can also make decisions not to invest in the other's territory and do not become the subject of BIT's legal relationship. But this is how they play games based on various reference factors (various functions and variables). Moreover, the process of this game is not one-time process, but multiple game process. More importantly, one of the main purposes of signing bilateral investment agreements is to attract investment from both sides to each other's territories. If the bilateral investment agreement did not play such an effect, the signing of this agreement is some kind of failure. Therefore, in BIT's legal relationship, in addition to the country, many investors within the two countries are also involved in the main game. The participation of investors is very important, because the signing of BIT will be meaningless in the absence of these investors.

\section{The Purpose of GAME - PreAmble to BITs}

The purpose of the treaty usually appears in the preamble to the treaty. Although they are only general principles, which does not involve the specific rights and obligations, they are of great significance for interpretation of the treaty ${ }^{[2]}$.

The purpose of BIT is also in the preamble, which can be understood as a clearer manifestation of the purpose of treaty between the two parties; Or from the perspective of game theory, it can be understood as the game range between the two parties. That is, the game involved in BIT is only within the scope of the preamble to the treaty, can not be extended to other areas.

The preamble to the BIT generally mentions the parties' willingness to strengthen bilateral economic cooperation and the encouragement and protection of investment, and believes that the encouragement and protection of foreign investment will be beneficial to the economic cooperation between the two sides. Such as the provisions in Germany's BIT module: ...Both sides have a strong desire to strengthen economic cooperation and create favorable investment treatment for foreign investment in the other side. The encouragement and protection of investment will help stimulate the private economy and increase the well-being of both parties... ${ }^{[3]}$

The BIT preamble signed by China is generally simpler. The common preamble such as the BIT Re-signed by China and France in 2007 provides: “...desiring to strengthen economic cooperation between the two countries and for this purpose, to create favourable investments conditions for Chinese investors in France and French investors in China, have agreed as follows: ..." ${ }^{[4]}$. The preamble to BIT signed by China and Canada in 2012 is even simpler: The two Contracting Parties further recognize the need to promote investment based on the principle of sustainable development, and they hope to strengthen their economic cooperation on the basis of equality and mutual benefit and reach an agreement as follows... ${ }^{[5]}$.The preface to the agreement between China and
Belgium-Luxemburg Economic Union in 1984 is somewhat complicated, and the general contents are as follows: "desiring to strengthen their economic cooperation by creating favourable conditions for investments by investors of one Contracting Party in the territory of the other Contracting Party; recognizing that the reciprocal encouragement, promotion and protection of such investment will be conductive to stimulating business initiative of the investors and will increase prosperity in both Contracting Parties; desiring to intensify the cooperation of both Contracting Parties on the basis of equality and mutual benefits; have agreed as follows:..."[6].

By comparison, the wording and content of Preamble to the BIT signed by United States is more complex. The main contents of preabmle to BIT between US and Uruguay are as follows: “...Desiring to promote greater economic cooperation between them with respect to investment by nationals and enterprises of one Party in the territory of the other Party; Recognizing that agreement upon the treatment to be accorded such investment will stimulate the flow of private capital and the economic development of the Parties; Agreeing that a stable framework for investment will maximize effective utilization of economic resources and improve living standards; Recognizing the importance of providing effective means of asserting claims and enforcing rights with respect to investment under national law as well as through international arbitration; Desiring to achieve these objectives in a manner consistent with the protection of health, safety, and the environment, and the promotion of consumer protection and internationally recognized labor rights; Having resolved to conclude a Treaty concerning the encouragement and reciprocal protection of investment; Have agreed as follows... ${ }^{[7]}$. . We can see from the preamble above United States' deep concern in promoting investment cooperation, developing investment protection, establishing a stable investment framework, facilitating settlement of disputes with investment, and health, safety, environment and labor.

And the United States also noticed the importance of preamble to BIT in interpreting the treaty. The U.S. government mentioned in the ADF v. U.S. Case that when considering the NAFTA, the Arbitral Tribunal should consider the text of the agreement, preamble, annex and other relevant agreements and legal documents. The BIT between United States and Albania make it clear that the preamble plays an auxiliary role in interpreting the treaty and in determining the scope for mutual consultation between the contracting parties to resolve the disputes ${ }^{[8]}$.

Why did the US BIT make the BIT preamble so complicated? What impact will this have on the development and practice of BIT? This needs further observation and analysis.

However, from the preamble to the BIT, we can clearly see that the purpose of the contracting parties is to promote and protect foreign investment from each other's terrirories and to strengthen economic and trade cooperation so as to promote economic development and people's welfare in both countries. From the view of game theory, this is a cooperative game model. The purpose of the two parties to reach an agreement is to try to play the game through mutual cooperation and to 
attract orderly flow of capital into the host country from the capital-exporting country. In this way, on the one hand, it has promoted the economic development of the host country; and on the other hand, it has also found a safe and reliable investment destination for the capital of the capital-exporting country. If both parties' desire to conclude an agreement can be fulfilled, this BIT can be regarded as a successful cooperative game. But even in a cooperative game, there still be things contrary to wishes. After the signing of BIT between China and Canada in 2012, the Canadian business community hopes to have more Canadian investment going to China, but many Canadians suspect that the agreement has actually caused more Chinese investment flow into Canada ${ }^{[9]}$. There are also some countries that intend to protect their own investment in other's territory when signing BITs, but in fact the effect is not very significant.

\section{DEFINITION OF INVESTMENT - FURTHER REFINEMENT OF GAME SCOPE}

The definition of investment terms is a prerequisite for every bilateral investment agreement, but also one of the most important terms. The terms of investment definition not only determine the scope of treatment or rights and obligations stipulated by the BIT, but also the basis for the parties to play the game.

There are many types of investment definitions in international BIT practices. According to research conducted by the United Nations Conference on Trade and Development (UNCTAD), the definition of "investment" in BITs generally falls into three categories: asset-based investment definitions, enterprise-based investment definitions and transaction-based investment definitions.

\section{Asset-based definition of investment}

In the BITs which accept the asset-based investment definitions, Contracting Parties allow or accept "investment" according to their respective laws and regulations as the protection of investment agreements.

The definition of investment in the BIT model of 2004 and of 2012 by United States is also asset-based ${ }^{[10]}$, although it provides a more detailed listing of the specific forms of investment. The first provision of the investment definition is as follows: 'Investment' refers to the various assets with investment characteristics controlled directly or indirectly by investors, including capital or other resources, expected benefits or risks to be borne. The form of investment includes:

(1) enterprises; (2) shares, shares and other forms of equity returns of an enterprise; (3) corporate bonds, unsecured corporate bonds, other bonds and loans; (4) futures, alternative stocks and other derivative products; (5) Turnkey Contracts, Engineering Contracts, Management Contracts, Production Contracts, Concession Contracts, Income Sharing Contracts and Other Similar Contracts; (6) Intellectual Property Rights; (7) Concessions, Delegations, Authorizations Granted under Domestic Laws and other similar rights; (8) other tangible or intangible property, movable or immovable property and related rights such as leasing, mortgage, liens and pledges.

2. Enterprise-based definition of investment
Another way to define investment is to focus on 'business ventures' or 'controlling interests in commercial ventures'. Some treaties define investment as including establishment and merger of commercial enterprises and also include ownership of an enterprise. This type of investment definition is sometimes referred to as 'enterprise-based definition' ${ }^{[11]}$.

The definition of 'investment' in the Canadian BIT model is a typical example. The first article of the model provides: "Investment" refers to: 1. (Establishment) of a business; 2. (Acquire) a company's shares; 3. (Acquired) Corporate Bonds; 4. Loans to business; .. 6. Having a stake in the business can be the owner's share of the business's revenue and profits; 7 . Having a stake in a business enables the owner to distribute the business property when the business is dissolved, except for bonds or loans in 3, 4, or 5; 8 . Real or other intangible property expected to be used or for economic or other commercial purposes; ... ${ }^{[12]}$.

\section{Transaction-based definition of inevstment}

The transaction-based definition of investment emphasizes cross-border flows of capital and related assets during the investment process, by the means of foreign direct investment (FDI) or acquisitions. The OECD's definition of investment in the Code of Liberalization of Capital Flows is typical of definition of this kind ${ }^{[13]}$.

The three types of definitions of investment, regardless of type, the scope may vary accordingly. For both contracting parties, the investment definition shows what form of investment the host country welcomes. These forms of investment, if inconsistent with the provisions of its domestic law, is at least not in conflict with domestic law. For capital-exporting countries, definition of investment shows what kind of investment the capital-exporting government is willing to protect; For capital-importing countries, the investment definition shows what type of investment is acceptable to the host country. From the view of game theory, the definition of investment shows that what is the target of the game for both sides. Or we may say that the object that both parties are willing to attract or protect is investment definition. With a clear definition of investment, the two sides of the game will have a more secure game foundation.

\section{Game Process - Negotiation AND Signing of BIT}

According to the game theory, the game is divided into dynamic game and static game, bilateral game and multilateral-game. There are many participants in the legal relationship involved in BIT, because although BIT is signed by the two governments, the main body affected by BIT is the large number of investors in both countries. The decision of these subjects in the process of investment is certainly a dynamic process of multi-party game. Moreover, investors in these two countries will not only invest in each other's country, they may also consider the investment in other countries which will involves the BITs that their own governments signed with other countries. Therefore, in such a game, the participants are numerous, which are basically divided into two categories: the first category is national governments, who decides whether or not to sign the BIT in such a game; The second category is domestic investors in all countries, who make investment 
decisions based on their own risk appetite, areas of investment, country preferences, legal systems, customs, etc.

In this decision-making process, BIT is only one of the factors for reference. The characteristics of this factor are: relatively stable, more transparent, highly specialized. Therefore, when investors make decisions based on this factor, they usually do not show too many irrational behaviors, because some large investment projects usually have professional legal services. But one of the most obvious features of investment disputes is hysteresis. If the investor's understanding of the terms of the BIT deviates, it is generally found later after the dispute arises and then submits the dispute to arbitration, and after one to two years they get the result. The impact of such adverse outcomes on this investor and its impact on other investors' decisions may be lagging behind.

However, the transaction cost of signing international treaties is very high, such as various negotiating fees, protracted negotiations and so on. High transaction costs make it impossible for BIT to make multiple changes in a short period of time after it is signed. It is so often that a BIT has not been revised for decades after its signing. Some BITs did not renew after the expiration date.

For BIT contracting parties, the same treaty may have different effects on the two countries. For developed countries, the purpose of signing BIT is mainly to protect their investment abroad. For developing countries, the signing of BIT serves to attract foreign investment. Therefore, the purpose of contracting is not the same for both contracting parties.

\section{The EFFECT OF THE GAME - The NATURE AND FUNCTION OF BIT}

As a bridge between the legal system of investors' home and host countries, BIT has a special function between the two countries and between investors.

On the one hand, the rules contained in a BIT constitute a constraint on the country of the signatory country. This kind of restraint comes from international law, but the restraint of such international law does not require the signatory to adjust domestic law as most internatioal treaties requires(In fact, it is impossible for signatories to make frequent changes to their domestic laws because of a newly signed BITs). It only requires the contracting parties admit that investors, if they think their legitimate rights and interests contained in the BITs have been harmed, may go to domestic courts for prosecution or submit international arbitrations. If one case be submitted to a domestic court for prosecution, the domestic courts will have to review the BIT clauses signed by both countries when they hear the case and decide whether the legitimate rights and interests of investors are infringed upon by domestic measures (or government actions).

If submitted to international arbitration, then the international arbitration tribunals have the opportunities to review the government behavior(or measures) of host country and decide whether it is in violation of international treaties (BIT). That is why many developing country governments are cautious about the internatioal disputes settlement mechansm.
For investors, when investing in the host country, he must takes into consideration not only the legal requirements of their own government, but also the laws of the host country. Investors generally conduct feasibility studies and due diligence investigation prior to their investment so as to ensure that the project does not violate thedomestic laws and bilateral treaties (mainly BITs and free trade agreements) of the host counties. However, all investment disputes occur after the investment, such as the law of the host country changes which results in the expropriation or indirect expropriation of the investment projects; or investors holds that some measures or behaviors (including omissions) of the host government affect their legitimacy. At this time, if resorting to domestic courts or administrative departments has no meaning, investors will rely on the BIT dispute settlement mechanism, and ask the arbitration tribunal to make a ruling in accordance with the provisions of international treaties.

As a result, BIT has become a de facto stable term for investors. At the very beginning of the investment in the host country, investors always make investment decisions with the luck of mind, even though the investment environment in the host country is very poor and the political situation is unstable at the time. In making such a decision, investors did not claim the treatment set forth in the BIT clauses, only hoping the host country would not change the law at that time and the political situation to be stable.

Therefore, the value of most of the terms(other than market access) in BITs can be considered to give investors a reasonable expectation or to bind the government. Then investors can form a certain expectant interest to the government in the established political and legal environment. Investors are faced with the operational risks and market risks, which are to be judged and burdened by investors themselves, while the political risks need to be borne by the government. The government must not only ensure that it is not a risk maker itself, but also ensure that the domestic population is not a risk maker.

Therefore, BIT is actually a guarantee or promise to investors between the governments which make overseas investors believe that their investment and legal rights in the host country will be guaranteed by international treaties ${ }^{[14]}$. BIT Contracting parties, as agents for the domestic population or investors, just conclude a contract that gives mutual promises to each other's investors. At the same time, the signing of the BIT can not only affect the investors from courntries which have signed BIT with each other, but also those investors who have not signed BIT with that country. Because the number of BITs that one host country has reached with other countries is seen as a signal to attract global FDI inflows and safeguard the interests of overseas investment. Moreover, the more BITs one country signs, the stronger this signal becomes. ${ }^{[15]}$

\section{CHINA 's BITS WITH COUNTRIES ALONG B\&R AND SUGGESTIONS}

\section{A. China's Investment in Countries along B\&R}

In the past ten years or so, China's direct investment in countries along $\mathrm{B} \& \mathrm{R}$ has experienced rapid growth and is faster than the overall growth rate of China's outward 
investment. According to the statistics from the Ministry of Commerce, apart from the traditional trade in goods, the B\&R Initiatives have also performed well in investment and construction. According to statistics, from January to October 2017, Chinese enterprises added a total of US \$ 11.18 billion to 53 countries along the B\&R, accounting for $13 \%$ of the total. In the meantime, Chinese enterprises newly signed contracts with foreign countries for consturcting projects in 61 countries along the B\&R, amounting to 102.07 billion U.S. dollars, up $21 \%$ over the same period of last year ${ }^{[16]}$.

However, the distribution of China's direct investment in countries along the B\&R is very different and unevenly distributed. ASEAN is China's most-invested area along the B\&R. West Asia and the Commonwealth of Independent States (CIS) are two areas which received large-scale direct investment from China and also see relatively rapid investment growth since 2010. From the investment model perspective, China's investment in countries along the B\&R is dominated by greenfield investments, supplemented by mergers and acquisitions. During 2005-2015, 63.5\% of China's investment in the countries along B\&R took the form of greenfield investments and 36.5\% adopted merger and acquisition. China's industrial structure for large-scale project investment in areas along B\&R has evolved from single energy industry to a multi-dimensional structure featuring energy sources, transportation, finance, technology, real estate and agriculture $^{[17]}$.

\section{B. The Practice of China 's BITs with Countries along B\&R}

According to the statistics of the Ministry of Commerce, by the end of 2016, China had signed 56 BITs with countries along the B\&R.

Among the 64 countries along B\&R, there are developing countries, developed countries as well as economic transition countries in Central and Eastern Europe. Specifically, 13 of them are EU member states, and 10 of them are ASEAN members, 23 of them are the countries which had signed BITs with US ${ }^{[18]}$. One of the reasons for the slow progress of BIT negotiations between China and the EU is that the countries in EU have different appeals and it is difficult to reach consensus in the BIT negotiations. Among the 16 countries in Central and Eastern Europe, the economic situation is uneven, and different countries have different attitudes toward China's foreign investment. And 10 of them are ASEAN members. Of the 10 countries, except for Singapore, they are all developing countries, and most countries had sluggish economic growth since the 1997 Asian financial crisis.

According to some scholars' empirical research, the signing of BITs can promote China's outward direct investment in the countries along B\&R, while there is a much obvious national differences. The promotion effect on investment in developing countries is more obvious, and the promotion effect on developed countries is not significant ${ }^{[19]}$. Research by Li Jiang, Wei Ping etc. (2017) also shows that signing BITs can safeguard the safety of Chinese enterprises and promote Chinese enterprises' direct investment in the B\&R countries. At the institutional level, due to the risk of institutional differences, BIT has a greater role in promoting China's investment in developing countries. This may be related to the generally low quality of institutions in developing countries and the investmet in such coutries needs more protection from BITs.

\section{Suggestions}

According to the above discussion, this article hold that in order to promote investment in countries along the B\&R, China should speed up the signing and amendment of BITs among developing countries. Because the quality of these countries' law systems is low and institutional distance is big, the signing of BIT can effectively play the role of securing China's OFDI. The signing and amendment of BITs between the developed countries along the B\&R can be postponed because bilateral economic and trade relations may play a more direct role in China's outward investment. And moreover, most developed countries along OBOD are EU members and the BIT negotiations between China and the EU are under way. EU countries will not sign and amend the BIT with China alone at the present time. So China can just wait for the substantical progress of BIT negotiation between China and EU.

\section{REFERENCES}

[1] Zhou Linbin , Law Economics: Theory and Practice of China, Peking University Press, 2008, P55.

[2] The Oppenheim International Law, revised by Jenning, Watts, China Encyclopedia Press, Volume I, 1998, P663 ; Shao Jin, International Law, Peking University Press, Higher Education Press, 2014, P418.

[3] Campbell Mclachlan QC, Laurence Shore, Mattew Weiniger, International Investment Arbitration, Substantive Principles, Oxford University Press, 2007, P28.

[4] http://tfs.mofcom.gov.cn/aarticle/h/au/201001/20100106725132.html, as of 2018.7.5.

[5] http://tfs.mofcom.gov.cn/article/Nocategory/201111/20111107819474.s html, as of 2018.7.5.

[6] http://tfs.mofcom.gov.cn/aarticle/h/au/201001/20100106724246.html, as of 2018.7.5.

[7] https://ustr.gov/sites/default/files/uploads/agreements/bit/asset_upload_fi le748_9005.pdf, as of 2018.7.6.

[8] Tao Lifeng, The United States Bilateral Investment Agreement Study, Law Press, 2016, pp.28-29.

[9] See generally Gus Van Flarten, China Investment Treaty: Expert Sounds Alarms in Letter to Harper, The Tyee Oct. 16, 2012), http://thetyee.ca/Opinion/2012/10/16/China-Investment-Treaty/ [https://perma.cc/HL94-CT4X] [hereinafter Van Harten 1] (urging Canadian Prime Minister Harper and Minister Fast to reconsider their decision of ratifying the treaty). Cited from Yingying $\mathrm{Wu}$, State-owned-enterprises in China-Canada BIt, North Carolina Journal of International Law, Vol. XLII, 2017, P378.

[10] See Lu Jinyong, Yu Jinsong, Qi Chunsheng. New Comments on International Investment Treaties [M]. Beijing: People's Press, 2007, pp. 270-275 Also see https://ustr.gov/sites/default/files/BIT\%20text\%20for\%20ACIEP\%20Me eting.pdf, as of 2017/8/25.

[11] Scope and Definition, UNCTAD Series on issues in international investment agreements, UNCTAD/ITE/IIT/11 (vol. II), UN publication,1999, P31.

[12] See Lu Jinyong, Yu Jinsong, Qi Chunsheng. New Comments on International Investment Treaties [M]. Beijing: People's Press, 2007, pp.304-305.

[13] Available at http://www.oecd.org/dataoecd/14/13/1935919.pdf, as of 2017/8/23.

[14] Bento, L. Time to Join the 'BIT Club' Promoting and Protecting Brazilian Investments Abroad[J]American Review of International Arbitration, 2013,24(2),pp. 271-324. 
[15] Busse, M., Kniger, J.,Nunnenkamp,P. FDI Promotioin through Biliteral Investment Treaties: More than a Bit? [J] Review of World Economics, 2010, 146(1), pp.147-177.

[16] http://fec.mofcom.gov.cn/article/fwydyl/zgzx/201711/20171102672740. shtml, as of 2017.12.10.

[17] Wang Yongzhong, Li Xi Chen, working paper No. 201703, Institute of World Politics and Economics, Chinese Academy of Social Sciences, May 2017。

[18] Zhu Wenlong, On the Transformation of China's Investment Agreements with the Belt and Road Initiatives along the B\&R, [J] Journal of Yunnan University, 2016, No.5, pp.115-123.

[19] Xu Xiaoping, Lu Jing, Li Jiang, The Impact of Signing Bilateral Investment Agreements on China's OFDI - An Empirical Study Based on the Countries along the B\&R, [J] Industrial Technology Economics, 2016, No.5, pp.64. 